\title{
Projectification and Partnering: An Amalgamated Approach for New Venture Creation in an Entrepreneurial Ecosystem
}

\begin{abstract}
The creation of a new venture is at the heart of entrepreneurship. Chinese governments at different levels are proactive in promoting the entrepreneurial ecosystem (EE) and fostering new venture creation (NVC). However, it is still far from clear how governments as focal actors in the EE affect and regulate the process and pattern of NVC. This study borrows from the theory of temporary organization and conducts a comparative case study of two entrepreneurial projects in the Hangzhou Dream Town EE. This study proposes an integrated conceptual framework to illustrate NVC in two dimensions of projectification (the process of NVC) and partnering (a pattern of NVC) and specifies that the main role of local governments is as a sponsor, feeder, and endorser in that order. The three functional roles enable local governments to catalyze the creation of new ventures through projectification and partnering. Our study not only contributes to the literature on entrepreneurship, governance theory, and the theory of temporary organization but also provides an actionable approach for governments to foster new ventures, especially in transition economics such as China.
\end{abstract}

Keywords: entrepreneurial ecosystem; governance; new venture creation; projectification; partnering. 


\section{Introduction}

Today the entire global economy is focused on innovation and entrepreneurship (Kuratko and Hornsby 2018), and the creation of a new venture is at the heart of entrepreneurship (Auschra et al. 2018). As engines of economic development, productivity growth, and employment, new ventures have received a great attention (Henrekson and Johanson 2010; Soederblom et al. 2015). In the US, net job growth occurs almost exclusively through new ventures (Soederblom et al. 2015); in China, it was reported in 2017 that 16,000 newly enterprises are born every day. New ventures are formed in the world at an exponential rate (Audretsch et al. 2018), and new venture creation (NVC) has become the most important business concept of the twenty-first century (Kuratko and Hornsby 2018).

Although important, the prospects of new ventures are very uncertain, and the majority of them inevitably fail because of their own vulnerabilities (Sarasvathy, Menon, and Kuechle 2011; Soederblom et al. 2015) and the liability of newness (Aldrich and Fiol 1994; Zhang and White 2016), exacerbated by complex technology (Carayannis and Campbell 2009; Bruneel, Spithoven, and Clarysse 2017), scarce resources (Spigel 2017; Acar, Tarakci, and Knippenberg 2018), and a turbulent environment (Stam and Spigel 2016; Spigel and Harrison 2018). Because of the importance and vulnerability of new ventures, governments and nongovernmental grant-making organizations around the world have developed and implemented policies to support entrepreneurs and increase the success rate of new ventures (Auerswald 2015; Soederblom et al. 2015), with a broader view of an "entrepreneurial ecosystem (EE)" focused on listening to entrepreneurs and enabling interactions between relevant actors (Stam 2015; Isenberg and Onymeah 2016; Colombo et al. 2017; Ács et al. 2018).

China faces several challenges, with an aging population, the potential for falling into the middleincome trap, and a new normal in the economy, so all levels of government in the country have been 
directed to become more innovative and entrepreneurial in order to propel sustainable growth (Liu et al. 2017). Some local governments promote the "creation of an ecosystem" (Isenberg 2010) and praise their cities as having an EE. In the emerging new context of EE, this implies that the function of previously existing incubators, accelerators, and research parks is being altered to make them more comprehensive, systematic, and integrated (Isenberg 2014; Visnjic et al. 2016). EE is defined as a dynamic, open, selfregulating network, in which many different types of actors are interdependent and interactive (Salmador and Bueno 2005).

Furthermore, governments increasingly acknowledge the importance of markets, private enterprises, and favorable institutional conditions as determinants of a well-functioning EE (Liu et al 2017), and the traditional governance of controlling for organizations and systems are being phased out. Public leaders should emphasize "venture creation" and help them "grow organically" (Isenberg 2010) and "stress the roots of new ventures" (Stam and Spigel 2016), because "An ecosystem is about performance and performance is what economics is about" (Ács et al. 2017), and entrepreneurship and entrepreneurial activities are important outputs of such a system (Stam and Spigel 2016). The entire EE is self-sustaining, and the increasing profit of existing companies and the newly emerging new ventures are becoming the indicators of EE performance (Salmador and Bueno 2005; Isenberg and Onymeah 2016).

The extant literature on EE with respect to new venture creation has a limited understanding of its processes and patterns, let alone the influence of the institutional environment or the role of governments (Tolbert et al. 2011; Fled 2012; Stam and Spigel 2016; Ács et al. 2017; Adner, 2017; Auschra et al. 2018). To fill these research gaps, we pose the following research questions.

\section{RQ1: What is the process and pattern of NVC within the EE context?}

RQ2: How do governments as focal actors in EE affect and regulate the process and pattern of NVC? 
To answer these questions, first, we adopt an integrated approach that combines a contextualized explanation (Welch et al. 2011) and processual approach (Abbott 1995; Van de Ven 2007; Liu and Xing 2009) as well as employing the theory of temporary organization (Lundin and Soederholm 1995) to conducting an exploratory case study of the Hangzhou Dream Town EE (hereafter, Dream Town) and two representative new ventures. In doing so, our study moves away from a simplistic and static way of treating a new venture as an outcome, which is often a characteristic of extant studies, and draws a roadmap for NVC that directs entrepreneurs to attend to a new venture's transition. Second, we examine the distinct and altered role of governments in the processes and patterns of NVC, to help governments design policies and take action in terms of contextualized roles: sponsors for product conceptualization, feeders for product materialization, and endorser for product commercialization.

\section{Literature Review}

\subsection{Characteristics of Entrepreneurial Ecosystems}

An EE, although it may vary in complexity and size, is "a network of interconnected and interdependent actors" (Mason and Brown 2014; Stam and Spigel 2016; Borissenko and Boschma 2017); it formally and informally combines to enable productive entrepreneurship (Baumol 1990) and mediates and governs performance within a local entrepreneurial environment or a particular territory (Stam and Spigel 2016), which could be in a corporate, local, or national context (Colombo et al. 2017). It is used as a vehicle to describe and explain opinions on how entrepreneurs interact with their environment (Minà and Dagnino 2017). These actions define an alignment structure in which various actors interact with one another to materialize a focal value proposition (Adner 2017). This is a future-oriented approach (Ács et al. 2017) that not only supports these actors as they develop new skills but also encourages them to pursue their 
entrepreneurial ideas, aiming to turn their ideas into an entrepreneurial project. In the end, NVC is an outcome of entire entrepreneurial process (Hornsby et al. 2009) that, from a systemic perspective, includes networks of entrepreneurs, leaders, finance, talent, knowledge, and support services (Stam and Spigel 2016).

Traditionally, EE is a spatial concentration of firms and associated nonmarket institutions, among which the anchor tenant is usually a large firm, acting as catalyst of the newborn EE that is pivotal in the transformation of the local environment and in spawning new entrepreneurship (Colombelli, Paolucci, and Ughetto 2017). With innovation and entrepreneurship initiatives, it thrives, along with the creative process and personal growth, by providing a workshop space, where amateurs and professionals interested in various fields can collaborate on projects (Tweney 2009; Rivas 2014). This institutional system facilitates the production and diffusion of new knowledge and the subsequent commercialization of that knowledge and bridges the gap between them.

An EE is also fundamentally a resource allocation system (Thomas 1999; Ács, Autio, and Szerb 2014) that is driven by the pursuit of individual-level opportunity through the NVC and is charged by government agencies with the provision of publicly funded support programs designed to foster entrepreneurship through tax benefits, the investment of public funds, and the removal of bureaucratic barriers to entrepreneurs (Neck et al. 2004; Cannone and Ughetto 2014; Mason and Brown 2014; Spigel 2017; Colombelli, Paolucci, and Ughetto 2017). In addition, the entrepreneurial support networks consisting of private institutions and financial investors (e.g., venture capital funds, business angels, banks) assist in entrepreneurial firm formation and growth (Kenney and Patton 2005; Colombelli, Paolucci, and Ughetto 2017).

\subsection{Processes and Patterns of New Venture Creation}


This EE approach has rapidly developed since the seminal work by Valdez (1988) introduced it to aid in understanding new business formation. It applies ecological systems' thinking (Ács et al. 2017) and has emerged as a popular concept for explaining the persistence of high-growth entrepreneurship and the emergence of new ventures (Spigel 2017). Contrasting to some scholars view that new venture is an outcome of the availability of certain factors, such as capital, opportunity, human resources, and the social and cultural environment, the social constructionists argue that new venture creation is the consequence of an individual's ongoing sensemaking and enactment of their environment (Lam 2004; Davidsson and Gordon 2012), new ventures and entrepreneurial firms are considered indicators of the performance of EE and are essential to the performance of the entire ecosystem (Colombo et al. 2017), energizing global economies (Kuratko and Jornsby 2018).

The organizational genesis is a journey from conception to birth (Jong 2006), starting with a gestation stage (Salamzadeh and Kirby 2017), continuing with the initiation of market activities to create value (Gartner 1985; Shaver and Scott 1991) or failing to achieve anticipated market acceptance (Becker, Knyphausen-Aufseß, and Brem 2015). Firm characteristics vary greatly, as do the entrepreneurs who create them (Gartner 1985). As the process of NVC is an iterative, nonlinear, feedback-driven, conceptual, and physical process (Bhave, 1994), it integrates four major perspectives: the individual(s) who start the venture, the organization that they create, the environment surrounding the new venture, and the process in which the new venture is started (Gartner, 1985). It also includes several activities, such as opportunity recognition, commitment to physical creation, establishment of production technology, organizational creation, product creation, linking with markets, and customer feedback (Bhave 1994).

In the context of EE, the collaboration for NVC takes place among loosely connected individuals, teams, and organizations, and the pattern of NVC has parallels with project-like organization (Auschra et 
al. 2018), in terms of a temporary organizational form characterized by time and budget constraints and geared toward fulfilling goals in a team environment (Lundin and Söderholm 1995; Lindgren and Packendorff 2003; Midler and Silberzahn 2008; Bakker 2010). Projectification (Midler 1995), as temporary organizational settings for new venture creation, features the four basic concepts of time, task, team, and transitions. Auschra et al. (2018) argues that the process of NVC in an EE is "project-like" to a considerable degree - that is, an entrepreneurial team has to carry out different parallel or serial tasks within a designated time frame because it has limited financing. At the same time, by selecting resourcerich and complementary partners, an entrepreneur carries out the entrepreneurial activities and interacts with partners that influence the pattern of NVC (Jiang and Tornikoski, forthcoming).

\subsection{Government Governance and Intervention}

Given the productivity growth, economic development, and new employment, governments and multinational institutions such as the World Bank have become increasingly interested in identifying and implementing programs to support entrepreneurs and new ventures (Auerswald 2015). Policies in many member countries of the Organization for Economic Cooperation and Development emphasize start-ups and support for growth-oriented entrepreneurship (Mason and Brown 2014). However, some scholars describe a blanket policy focus on new start-ups as "bad public policy" (Shane 2009) and claim that government regulation based on fiscal advantage is harmful for the emergence of EE (Kleiner and Krueger 2013; Auerswald 2015), thus NVC. New ventures must be exposed early to the market's rigors (Isenberg 2010) as much as possible.

Scholars have long realized that government plays a critical role in formulating rules, laws, and policies

for the business environment (Hillman, Keim, and Schuler 2004; Colombo et al. 2017) and a more 
significant role in transition economies than in mature economies (Bruton, Ahlstrom, and Obloj 2008), because the government determines the pace of institutional transitions and develops the rules for behavior in the transition (Bruton, Su, and Filatotchev 2018). Government not only seeks to facilitate the transformation of social norms (Yiu et al. 2014) but also justifies institutional voids while institutions are evolving (Walsh, Bhatt, and Bartunek 2009). In transition economies, the government supports the new ventures in the form of traditional "money-based" policies, such as subsidies, tax incentives, and R\&D grants, which are necessary in the early stage (Brown and Mason 2014), as well as using specific policy support approaches and instruments to nurture NVC.

Institutions influence whether and how potential entrepreneurs open a business (Herrmann 2010). In the early phase of NVC, entrepreneurs often rely on continuous external funding to secure the survival of the new venture until a sturdier and more permanent organization can be formed (Auschra et al. 2018). The granting of external funding is always connected to different institutionalized expectations, therefore individual entrepreneurial actions and the outcomes of those actions are regulated by institutions (Ács et al. 2014). However, the entrepreneurial team is the core actor in building and sustaining an EE (Stam and Spigel 2016). It can develop and contribute to interfirm networks and regional clusters (Pitelis 2012; Auschra et al. 2018).

The extant literature extends the study of promoting entrepreneurship and fostering NVC in EE. Although the broad literature on EE focuses on relational governance (Stam and Spigel, 2016; Isenberg and Onymeah 2016; Colombo et al. 2017; Spigel, 2017; Bruton, Su, and Filatotchev 2018), articles on the role of government is not specified clearly and contradictory due to the difference of institutionalization and contextualization. Whereas some papers try to understand the actors and networking (Ács et al. 2017; Kuratko et al. 2017; Spigel and Harrison 2018), few addresses how to create 
interaction and improve its quality. Some literature concentrates on NVC and impact factors (Lam, 2004;

Davidsson and Gordon, 2011; Spigel and Harrison 2017; Auschra et al. 2018), but papers on how the process of NVC has evolved and what patterns have emerged are not less summarized and concluded. In sum, they lead to a simplistic and static way of treating NVC as an outcome, without clarifying transitions in new ventures in terms of specific deliverables in subphases with the involvement of a partner. Thus, because new ventures are temporary organizations, we combine the contextualized explanation (Welch et al. 2011) and processual approach (Abbott 1995; Van de Ven 2007; Liu and Xing 2009) to provide a roadmap for NVC and examine the distinct and evolving role of governments in the processes and patterns of NVC.

\section{Research Design}

The research method adopted in this paper is theory integration from a case study (Yin 2014; Eisenhardt and Graebner 2007), which combines a contextualized explanation (Welch et al. 2011) and a processual approach (Abbott 1995; Van de Ven 2007). A qualitative method is chosen as the best way to arrive at an encompassing and co-evolutionary view (Burgelman 1983; Bhave 1994) on NVC in an EE. At the same time, with the advantage of abundant materials on the case study, inductive as well as research logic was used to generalize the specific empirics into a theorized framework, to increase conceptual clarity and operational manageability.

\subsection{Research Setting}

The research employed a single in-depth and longitudinal case design that probes all the influential activities and events to design an operational framework in a representative EE with two newly established entrepreneurial firms. The single empirical setting is Hangzhou Dream Town EE (hereafter, 
Dream Town), located in Zhejiang, China, established in August 2014, and active since March 2015. Dream Town is supported by the Zhejiang provincial government, initially for retention of ex-employees of Alibaba who got the stock-based incentive compensation when Alibaba went public in New York in September of 2014 and now is the birthplace of many start-ups. ${ }^{1}$ After more than three years of development, it has attracted more than 12,900 entrepreneurs, 1,341 entrepreneurial projects, 50 incubators and accelerators, and 1,170 registered investment institutions, with total capital under management of over RMB 263 billion. Dream Town provides the holistic nurturing for entrepreneurs and new ventures and has the slogan: "We provide the sunshine and rain, and you succeed by growing like a plant."

We selected Dream Town to implement "information-oriented selection" and "maximizing the utility of information" (Flyvbjerg 2006) for a few reasons. First, Dream Town is located in Zhejiang in eastern China, a region that has been one of China's key economic engines and has made a remarkable contribution to China's economic strength (Millman and Li 2017). Second, Dream Town is a newly emerging local EE, it has been a hub for internet 2.0 start-ups to upgrade traditional enterprises with new products, new sectors, and new business models. Third, Dream Town is considered by China scholars in entrepreneurship domain as a paradigmatic case that can be used as a representative of NVC. We also selected it because we had easy access to the local government and their entrepreneurs required for this study.

\footnotetext{
${ }^{1}$ Dream Town has been intensively reported on in the international media, such as Deutsche Press Agentur, Pittsburgh PostGazette of USA, Australian Associated Press, Kyodo Tsushinsha, Yonhap News Agency, Berita National Malaysis etc, because of its outstanding performance in entrepreneur cultivation and new venture creation. It has also attracted scholarly interest worldwide in different research domains.
} 
Further, the entire EE includes more than one unit of analysis to observe the evolution of new ventures from entrepreneurs to entrepreneurial team, to corporatized units, and finally permanent organizations. To conduct our analysis, we consider the entrepreneurial team the basic unit and examine the NVC as the output from interaction between the entrepreneurial team as the core actor and the government (and its agencies) as the focal actor. To generate new insights into how the EE shapes the NVC process, we focus on two entrepreneurial projects, Poly Health and Medoxygen, which went through the entire loop of new ventures emergence, better for processual and comparable study, see Table 1. These examples are market oriented (Poly Health) and technology oriented (Medoxygen) and in operation for more than 30 months, covering most of the period of Dream Town operations, enabling comparison and verification to the approach of projectification and partnering.

\section{\#\#\#Insert Table 1 here\#\#\#}

\subsection{Data Collection and Analysis}

We combine theory and empirical evidence to strengthen our analysis (Yin 2014), including interviews, site observations, findings in the literature, and documentation on Dream Town as an EE for public promotion and internal reporting. To gain insights on NVC in EE, we conducted in-depth interviews with key members of the government, entrepreneurial firms, and investment firms to compare our theoretical arguments and the empirical data. In these interviews, we used semi-structured face-to-face questionnaires at Dream Town from June 2016 to May 2018 which forms a two-year longitudinal interview study, we also retrieved the prior history from its inception to June 2016. The interviews comprise a total recorded time of 111 hours, in which each respondent was interviewed for a minimum 1.5 hours; see Table 2. Respondents were encouraged to describe complex issues in their own words. 


\section{\#\#\#Insert Table 2 here\#\#\#}

The inductive nature of the study demands that we suspend a priori expectations of findings (Dutton et al. 1997) and maximize the richness of data so as to create more sense. First, by reading all the interview materials and generating a detailed list of all the perceived characteristics mentioned by the respondents on the NVC process and the interactions of different actors, we created two groups of coding teams and defined inductive code categories. Then, we clustered these characteristics into segmented themes in which characteristics are considered themes if at least three respondents mention them. Two coding experts analyzed the interviews for the existence of these themes. In the end, we achieved good agreement of $95 \%$ between two coding groups. If any disputes arose about which theme the example fits, we discussed them until we reached agreement, and the data structure is illustrated in Figure 1.

\#\#\#Insert Figure 1 here\#\#\#

\section{Findings}

Dream Town is governed top-down by a "visible hand" (Colombo et al., 2017), led by the Zhejiang provincial government (ZPG) and governed by the Dream Town Steering Committee Office (DTSCO), which is likewise directed by the ZPG, controlled by the Hangzhou Future Sci-Tech City Management

Committee (HFSCMC), and operated by Greenroot which is an agency carrying on the local policies of the HFSCMC. The DTSCO is also deeply involved in the entire process of NVC, besides its assumed fundamental governance as "deployment" (Isenberg 2010; Mason and Brown 2014) and "coordination" (Ács et al. 2017) of EE. We document the evolution of NVC and the interaction between the entrepreneurial team and the local government.

\section{Phase 1: Product Conceptualization}


In response to Dream Town's initiative, various (potential) entrepreneurs and a range of academic and professional experts join together at an incubator and accelerator in a close geographical, institutional, and relational context (Colombelli, Paolucci, and Ughetto 2017). It is reported in local media:

"Here has formed the first-class environment and rich aroma for the gathering of talents. Talents from Ali, from Zhejiang University, from Zhejiang Province family enterprise and from overseas have become four important teams for Dream Town, who are referred to as the 'New Fourth Army."'

Entrepreneurs with clear identity and entrepreneurial intention gather at Dream Town, can connect with the preferred one of total 50 incubators and accelerators. Then the preferred incubator or accelerator will organize a seminar for challenging those entrepreneurial idea, including their rationale and methodology. The feedback will enable entrepreneurs to conduct a primary market survey. CEO of Poly Health stated:

"We approached Turtle incubator for helping business model renewal and facilitating business network building linking to my background. Our business plan was reshaped soon thereafter, highlighting my experience in medical devices and trending grand health service."

Then, depending on the maturity of their entrepreneurial ideas, entrepreneurs were encouraged to participate in a pitch presentation, organized by the DTSCO regularly on a monthly basis. Five experts form an expert panel for project review and Q\&A. During the presentation and Q\&A, the entrepreneurs receive many comments aimed at helping them to refresh the concept, model, and data of their project.

If the entrepreneurial project is promising in terms of its high potential in technology or market, it turns to ending of problem statement and verification and will be finally selected and sponsored by the government, mainly through subsidies from the DTSCO, and executed by the preferred incubator and accelerator. This is the first step for formal entry into Dream Town, meaning that the entrepreneurial project is formally initiated and thus at the starting point of projectification. 
At these monthly pitch sessions, entrepreneurs and their entrepreneurial projects are scrutinized, and the DTSCO selects the right people (identity of the entrepreneur) and evaluates entrepreneurial projects to improve the success probability. A small government subsidy as well as free workspace are granted to show the potential value of an entrepreneurial project for which the government agrees to act as a sponsor (Roberts 2011). As one entrepreneur stated:

"After our entrepreneurial project was supported by the DTSCO, so we obtained office space totaling 50 square meters, free of charge, ... at the center of Dream Town, ... including furniture, electrical power, wi-fi, and drinking water."

The granting of subsidies in Dream Town is similar to other regional practice, not a matter of government policy but, rather, a result of decisions made by individual officials (Yan and Li 2018). Because of the imperfect institutional environment and reliance on political connections in China, the receipt of government subsidies usually also depends on firm's special relationship with government officials (Chen et al. 2011). However, Dream Town employs online application and prompt evaluation to improve the transparency, which mostly avoids this kind of rent-seeking, attracting more entrepreneurs to participate. This kind of institutional setting maximizes the outcome of entrepreneurial action (Ács et al. 2014) and in turn creates an entrepreneurial culture and encourages entrepreneurial action. So, we formulate the following proposition:

Proposition 1: In the "product conceptualization" phase of NVC in an EE, the role of government is mainly as a "sponsor," with the aim of evaluating the potential value of entrepreneurial projects, and helping entrepreneur(s) turn an entrepreneurial project into an executable project.

\section{Phase 2: Product Materialization}


After entrepreneurs' ideas are accepted, their preferred incubator and accelerator assists them in product materialization. When the entrepreneurial project is formally kicked off for execution, the entrepreneur(s) will form an entrepreneurial team to refine the entrepreneurial idea based on feedback received at the pitch session.

Knowledge about product materialization, no matter how strong or weak the entrepreneurial team's prior experience, is enhanced and supplemented by the Dream Town community (Haas 1992). Entrepreneurs transfer the accumulated explicit knowledge to the external environment, where it is utilized and transformed back into a tacit form for their entrepreneurial project through "knowledge internalization" (Nonaka and Takeuchi 1995).

"Our company heavily rely on $R \& D$ and intellectual property rights. Patent registration plays an important role in demonstrating our technology advance, and we are able to complete those patents applications by learning a lot from Dream Town friends."

"The remarkable advantage here is in being close to the market. We have assembled a marketing expert panel internally and externally, which advises on product development and quality function deployment and helps us to swiftly bridge between product and market."

Product materialization is always constrained by resources and entrepreneurial team capability, so human and financial resources are needed. To relieve this burden, the DTSCO encourages entrepreneurs by providing financing, including seed capital and venture capital, to achieve a minimally viable product and in the end a marketable product. One entrepreneur stated:

"Based on our prior experience, we finished a prototype for a medical oxygen generator. We made a presentation at an entrepreneurial event, and it was immediately recognized by the DTSCO, which invested RMB 200,000 as seed capital, and this enabled us to go on to create a marketable product." 
After the minimally viable product (MVP) (Ries 2011; Lenarduzzi and Taibi 2016) is achieved as one milestone, the entrepreneurial team continues to pursue a marketable product based on MVP prototype and executes in the project management methodology, with clear and refined project deliverables, as well as solid and revisited milestones, as a commitment or signed contract with the funders. Consequently, the local government further allocates financial resources to boost the realization of a marketable product. In the past three years, 250 (18.6\%) of entrepreneurial projects were awarded RMB 200K (from DTSCO's angel capital) after evaluation of the project deliverables. Managing Director of Medoxygen mentioned:

“In May 2017, we were granted venture capital of RMB 800,000 to finance product development, onequarter of which is from the ZPEHIM through DTSCO. It was very important because it enabled us to order the main equipment, then we successfully complete our first on-site medical oxygen plant in August 2017 and present it to our international clients."

Hence, in the product materialization, the entrepreneurial team geographically assembles in one sample place (Dream Town) and actively participates in entrepreneurial events and connects with the epistemic community (Bathelt, Malmberg, and Maskell 2004; Johnston, Robinson, and Lockett 2010) created by the local government, which in turn enables learning processes, sharing of tacit knowledge, and building of social capital. That knowledge could be partially tacit and partially explicit, the knowledge (particularly the tacit knowledge) is hardly evaluated in transparent manner of market trade-off (Nonaka and Takeuchi 1995). If government assessments are independent and technically sophisticated, knowledgeable government officials (Lerner 2002) can certify the product's marketability via multilayer assessments and many channels, including mentorship feedback. At the same time, attempts to reach this phase by entrepreneurial teams require the investment of resources that have opportunity costs. The provision of both seed and venture capital to facilitate product knowledge and materialization is the role of a feeder, Page 16 of 42 
in which a person or organization supplies the required resources (Feld 2012; Baldock 2015; O'Connor et al 2018). This can help the entrepreneurial team to signal its project preponderance (Yan and Li 2018) and thus boost its access to external resources. Therefore, we offer the following proposition:

Proposition 2: In the "product materialization" phase of NVC in an EE, the role of government is mainly as a "feeder," with the aim of facilitating knowledge generation for an entrepreneurial team to materialize products.

\section{Phase 3: Product Commercialization}

After product materialization, it is time for the new venture to commercialize the product, to prove the soundness of the business model, and to generate cash flow. At this point, it must establish a legal entity. Although legally registered, the new ventures are still in semi-formal or project-like organization because of the liability of newness. The ZPEHIM (through DTSCO) is the founding shareholder with venture capital of RMB 200,000, secured by a previously signed partnership agreement with the DTSCO.

Through these steps, the entrepreneurial team is becoming transformed into a corporatized unit oriented toward market development and supply chain management that later develops into a permanent organization (unless it fails), with supply chain and customer relationships. Chief engineer of Medoxygen mentioned:

"We cooperated closely with the existing supply chain for key components in a standardized and modularized approach, which sharply reduced the production cost, and received support from those cooperation partners."

To support business operability so as to verify the business model, the DTSCO introduced an industryguiding fund and promotes the legitimacy of a new venture, as needed. In addition, a financing workshop 
is held regularly with a bank in an investment-loan linkage program coordinated by the DTSCO. After the business operability is confirmed or validated, it is successful, and the DTSCO recommends a public listing on the Zhejiang Equity Exchange Center to obtain equity capital and more opportunities for exposure to investment institutions for the purpose of attracting venture capital.

Thus, during the phase of "product commercialization," the new venture can rapidly develop toward full functionality. At this time, it requires more close collaboration (Hosseini et al. 2018) to obtain resources and networking to overcome the liability of newness and promote its legitimacy, as well as connecting to a supply chain and customer relationships. As EE is characterized by a large number of loosely interconnected participants and organizations (Autio and Thomas 2014; Rong and Shi 2014), the professional agencies in the EE can play a key role in directing and shaping the entrepreneurial project. However, creating trust between actors in an EE to form this kind of collaboration (Hosseini et al. 2018) is necessary. The DTSCO acts as an endorser, that is, a person or organization that is authorized to sign a negotiable security or can shape the opinions of others (de Lange 2016) and create a superior institutional framework to coordinate these kinds of collaboration, including credit-based finance, strong business associations (Casper and Whitley 2004), and being the shareholder. The DTSCO's industryguiding fund and promoting equity exchange for the new venture are "direct or recessive" government guarantees (Yan and Li 2018) and enhance a new venture's access to external financing, because the banks in China display pro-government behavior. Nevertheless, a local government's endorsement provides the participating actors with control and accountability for a new venture (Hodge and Adams 2016) and catalyzes "peer-based" interactions (Mason and Brown 2014). Therefore, we suggest the following proposition:

Proposition 3: In the "product commercialization" phase of NVC in an EE, the role of Page 18 of 42 
government is mainly as an "endorser," with the aim of mitigating the liability of newness and promoting the legitimacy of a new venture.

Based on these findings, the government has a profound impact on new ventures in transition economies such as China, not only setting the rules and norms to regulate the competitive landscape but also directing involvement in interactions that affect new ventures' behavior and outcomes (Bruton, Su, and Filatotchev 2018). Dream Town is representative of successful practice in both the central government's strong support of entrepreneurship and the local government's experimentation in fostering EE and spurring NVC. Paralleling the entrepreneurial team as the core actor in an EE, the local government has a unique role in NVC in the Dream Town EE, illustrated in Figure 2.

\section{\#\#\#Insert Figure 2 here\#\#\#}

\section{The Development of An Amalgamated Approach}

Further to section 4 focusing on how to interact between the local government and entrepreneurial team, we would develop how the projectification approach frames the NVC process and how the partnering approach frames the pattern of NVC.

\subsection{The Projectification and Process of NVC}

NVC is an action-based process (Cardon et al. 2012) constrained by time and resources. Reflecting the 4T (time, team, task, transition) framework of temporary organizations (Lundin and Soederholm 1995; Lundin et al. 2015), projectification is widely used by local government and other institutional actors as common "working language" in dream town, to pivot the entrepreneurial project progressing and define its deliverables. 


\section{The Time Aspect of New Venture Creation}

Time, which is limited, is particularly important in time-to-market and time-to-financing. Time horizons and time limits (Lundin and Soederholm 1995) for new ventures are specified, which is crucial for entrepreneurial teams and interested parties to measure the maturity of new ventures and determine resource allocation. Time informs the entrepreneurial process in favor of a short-term orientation and incremental development (Auschra et al. 2018), usually one to three years for NVC, depending on the product and business characteristics. Further, the project schedule is integral to a solid business plan and is intensively challenged during conceptualization. At Dream Town, after an entrepreneurial project is selected and sponsored by the government, the project proposal and related contracts specify the way in which the work is undertaken, setting out milestones to be achieved to monitor progress toward NVC.

\section{The Team Aspect of New Venture Creation}

Although NVC can start with just an entrepreneur(s), or a small team, an entrepreneur(s) has to assemble a team whose members work on specified tasks. To gain the approval of an entrepreneurial project in the form of a business plan, the entrepreneur(s) has to assemble a team and work out strategies for task fulfillment. For better presence to potential investment institutions, a complementary entrepreneurial team is assembled with the help of local government and incubators \& accelerators, with well-balanced competence and expertise geared toward project-like organization (Ács et al. 2014; Autio et al. 2014; Auschra et al. 2018). Nevertheless, to support later business growth, a corporate unit (Rethelyi, Miskovits, and Szocska 2002; Ferry et al. 2018) is registered as an incentive regime between an entrepreneurial team and a permanent organization that is a fully functioning legal entity, to enable product commercialization to begin.

\section{The Task Aspect of New Venture Creation}


Entrepreneurship is action based and task oriented (Cardon et al. 2012). The entrepreneurs execute unique tasks, such as development of a business model and product market fit, which are essential for the enactment of the new venture (Auschra et al. 2018). At Dream Town, regardless of whether the venture is technology oriented or market oriented, five tasks (five verifications of entrepreneurial project, minimum viable product, marketable product, business operability and business expandability) matching three phases are predefined for tracking NVC and monitoring the performance of a new venture, and they are the criteria for allocating the resources consequently. For instance, the ZPFHIM reserves the seed and venture capital for a new venture for a minimally viable product and in the end a marketable product. But no entrepreneurial project is an island (Engwall 2003); it is linked to the value layer and contextualized activities, influenced by institutionalized norm, value, and routine in the EE. For instance, upon the validation of their deliverables, the ZPFHIM and other investment institutions step in, and they exert great influence on task refinement, which the entrepreneurial team has to acknowledge in most cases.

\section{The Transition Aspect of New Venture Creation}

Within a strict time constraint, the new venture undergoes various transitions. The process of NVC undergoes various transitions, too, in terms of changes in organizational structures as well as product or service adaptation (Auschra et al. 2018). They are similar but unique (Engwall 2003). First, the process has an institutionalized ending: either the new venture becomes permanently established or it vanishes. Second, reflecting the zeitgeist of temporal acceleration and time boundedness, projectification also has a serious impact on how entrepreneurs create new ventures in terms of the expectations and rules that are set forth explicitly and implicitly by the EE or related interested parties (Ács et al. 2014; Autio et al. 2014; Auschra et al. 2018). Third, the stakeholders can generate new insights into the current situation confronting organizations and represent a unique event as entrepreneurial teams evolve in their approach 
to creativity and innovation (Aubry and Lenfle 2012). Considering the 4T framework on NVC, we posit that:

Proposition 4: Featuring with transiting task in clear time span for entrepreneurial team, projectification frames the action-based process of NVC and is also reproduced in a similar but unique process of NVC in the context of an EE.

\subsection{Partnering and Patterns in NVC}

In the context of EE, pursuing an entrepreneurial project that turns into a new venture goes significantly beyond managing it—in particular project networking and developing partnerships. In NVC, the team is involved not only in project transition but also in organizational transformation. Because of this organizational change in form, it brings the "management dilemmas of the alleged flexibility of the organizational form in need for some stability" (Lundin et al. 2015).

Committed Entrepreneur(s): Stability in the Entrepreneurial Team

As discussed in section 5.1, the entrepreneurial team is in the driver's seat in managing the process of NVC, beginning with the entrepreneur, who pursues an entrepreneurial opportunity and exercises initiative by organizing a venture to take advantage of an opportunity and, as the decision maker, decides what, how, and how much of a good or service will be produced (Kao 1991). An entrepreneurial team consists of two or more persons who share a commitment to a venture's future and success (Schjoedt and Kraus 2009), the entrepreneurial team is similar to a top management team, that is, a group of people with management responsibility. Entrepreneurial teams are seen as social entities by themselves and by others, usually considered to be at the executive level with executive responsibility in the early phases of the venture. Throughout the process of NVC, the members of an entrepreneurial team are interdependent and 
remain relatively stable in the pursuit of common goals and the venture's success.

\section{Emerging Corporatized Unit: Fluidity of a New Venture}

As one of the institutional forms of a collaborative relationship (Aarseth et al. 2012; Børve et al. 2017;

Hosseini et al. 2018), partnering is widely seen as improving collaborative entrepreneurial project performance. The EE provides a melting pot of talent, investors, partners, and customers (Grabher, 2002), which influence the activities of start-ups. In addition, the practice of raising capital is also conducted in close cooperation with partners (Auschra et al. 2018). Considering the anticipation of cooperation partners and the contextualization of projects (Engwall 2003), partnering for NVC will bring variety in resource allocation, leading to product diversification, an open collaboration network in an EE provides more options for an entrepreneurial team to determine the compatibility of several critical decisions, thus the fluidity of new ventures in terms of the structure of shareholders, strategic positioning, and the product portfolio. The general fluidity of new ventures opens up for an entrepreneurial team able to find opportunities of various kinds in EE and in ongoing development at the time of entrepreneurial projects.

\section{Towards Permanent Organization: Legitimacy of New Ventures}

Permanent organizations are concerned with the long-term efficiency of the processes and with accomplishing an effective and durable outcome, defined by survival (rather than time), goals (rather than tasks), working organization (rather than teams), and continual development (rather than transitions) (Lundin and Soederholm 1995; Lundin et al. 2015). In contrast to permanent organizations, new organizations are always vulnerable to the liability of newness (Sarasvathy, Menon, and Kuechle 2011;

Soederblom et al. 2015; Zhang and White 2016), resulting from the constraints facing an entrepreneurial team and new ventures in emerging industries and their relative lack of sociopolitical legitimacy (Bruton, Ahlstrom, and Obloj 2008; Bruton, Su, and Filatotchev 2018). As shareholders, the local government and 
its agencies signal the quality of a new venture and promote its legitimacy in the form of corporatized unit that is in between an entrepreneurial team and a permanent organization. Corporatization is initially the process of transforming government agencies or municipal organizations into corporations (Ferry et al. 2018; Voorn, Thiel, and Genugten 2018). In the context of an EE, a corporatized unit represents a shift from an entrepreneurial team to one that is mostly involved in public-private forms of governance (Rethelyi, Miskovits, and Szocska 2002; Citroni, Lippi, and Profeti 2013). In summary, we argue that:

Proposition 5: Partnering allows the partners to anticipate entrepreneurial activities in various forms as an institutional force, shape the pattern of NVC, and promote the legitimacy of a new venture-both help a new venture to overcome the liability of newness.

\section{Conclusion and Implications}

At Dream Town, the local government, as the focal actor of an EE, brings visible or invisible links (topdown) to new ventures and emphasizes an entrepreneur and entrepreneurial team as the core actor in an EE that evolves naturally (bottom-up). The dual-centered entrepreneur and local government and the two streams (top-down and bottom-up) are concurrent to improve interconnections and their links with other actors in an EE, such as investment institutions and professional service providers, to maintain the dynamic but vigorous EE. At the same time, the two entrepreneurial projects examined here represent "market-oriented" and "technology-oriented" projects, respectively, in a comparative case study.

Although their entrepreneurial tasks are different, they implement a similar process of NVC: three entrepreneurial phases accompanying with five clear milestones and deliverables in projectification. They also share repeatable and reproducible patterns of NVC: the entrepreneurial team as the key actor and the government as focal actor, forming dual centers of interdependent entrepreneurial activities in partnering, 
thus promoting a transition in the organizational form of new ventures. The local government's role as sponsor, feeder, and endorser catalyzes the creation of a new venture.

\subsection{Theoretical Contributions}

In this study, we develop an integrated conceptual framework to illustrate the creation of new venture with two institutional forms: projectification and partnering. Projectification helps to frame the process of NVC to ease the execution of entrepreneurial projects over a lifecycle, and partnering allows the pattern of NVC to be shaped in anticipation of entrepreneurial activities. We integrate them for a better illustration of the dynamics and evolution of NVC, to provide insights on NVC as an action-based process in an institutional context.

Second, we differentiate three government roles during the creation of a new venture and reveal the different mechanisms in the context of an EE. In our exploration, we shed the light on government regulation and intervention as salient aspects of a new venture in the context of an EE, providing theoretical support for government intervention in an EE and elements of it, such as new ventures in transition economies and emerging markets.

Third, we introduce the theory of a temporary organization and 4T (time, team, task, and transition) framework to demonstrate the prevalence of projectification as a fundamental development in new ventures toward just-in-time planning and execution despite environmental turbulence, to deepen nuanced

understanding on the theory of temporary organization and expand its application in the domain of entrepreneurship, especially in NVC.

Last but not the least, we refine the classic rendering of NVC with a product (and service) orientation in terms of conceptualization, materialization, and commercialization and with more organizational 
resource support, while recognizing the process as iterative and nonlinear, comparable to the three core variables of NVC and three crucial phases of launching a new business. We offer insights on the dynamics as well as clear tasks and deliverables in each phase.

\subsection{Practical Implications}

Our findings indicate that the "top-down" approach prevails in transition economics, such as China, and this implies an EE can be created from scratch or at least shaped by policy makers and is reflected in a top-down governance structure. This provides a reference for governments in transition economies to mobilize power and resources to intervene in economic development and catalyze the emergence of new ventures.

We also summarize the example of Dream Town, which demonstrates local experimentation by the Zhejiang (local) government that aligns with central government policy but tailors it to local conditions. Therefore, local governments need to appropriately adapt central government policy for local economic development, to maintain local institutional and competitive advantages.

Lastly, we also show that, regardless of whether new ventures are technology oriented or market oriented, they share comparable creation processes, encompassing repeatable and reproducible patterns. Both the process and pattern of NVC provides the entrepreneurial team with a roadmap for being the core actor and interacting with other actors, in particular with the local government.

\subsection{Limitation and Future Directions}

We offer three suggestions for deeper scholarly investigation.

This study is just with two new ventures, due to the limited availability of information on the entire 
process of NVC, so it could cause concerns about external validity. If and when more data become available, future researchers could build on our work, without our trade-offs between the opportunity to gain insight and the currently incompletely documented phenomena.

Meanwhile, although we perform a two-year longitudinal interview study to reflect the dynamics of NVC, we still cannot fully compare the two new ventures at three phases in view of their sectional data, which require more samples with a much longer time period for longitudinal observation.

Third, the Dream Town example calls for more studies and investigations by government and academia, so as to make a comparison with other Chinese EEs and EEs in other transition economies, to determine whether factors other than the government's role are salient, to duplicate our results. 


\section{References}

Aarseth, W., Andersen, B., Ahola, T., and Jergeas, G. 2012. Practical difficulties encountered in attempting to implement a partnering approach. International Journal of Managing Projects in Business, 5(2): 266-284.

Abbott, A. 1995. Sequence analysis: New methods for old ideas. Annual Review of Sociology, 21(1): 93113.

Acar, O. A., Tarakci, M., and van Knippenberg, D. 2018. Creativity and Innovation Under Constraints: A Cross-Disciplinary Integrative Review. Journal of Management, 0149206318805832.

Acs, Z. J., Stam, E., Audretsch, D. B., and O’Connor, A. 2017. The lineages of the entrepreneurial ecosystem approach. Small Business Economics, 49(1): 1-10.

Acs, Z. J., Estrin, S., Mickiewicz, T., and Szerb, L. 2018. Entrepreneurship, institutional economics, and economic growth: an ecosystem perspective. Small Business Economics, 51 (5): 1-14.

Adner, R. 2017. Ecosystem as structure: an actionable construct for strategy. Journal of Management, 43(1): 39-58.

Ajam, M. 2011. “Entrepreneurship and project management: The missing link.” PM World Today, 13(4): 178-193.

Aldrich, H. E., and Fiol, C. M. 1994. Fools rush in? The institutional context of industry creation. Academy of Management Review, 19(4): 645-670.

Aubry, M., and Lenfle, S. 2012. Projectification: Midler's footprint in the project management field. International Journal of Managing Projects in Business, 5(4): 680-694.

Auerswald, P. E. 2015. Enabling entrepreneurial ecosystems: Insights from ecology to inform effective entrepreneurship policy, SSRN Electronic Journal, 7(2): 3-10. 
Auschra, C., Braun, T., Schmidt, T. and Sydow, J. 2018. Patterns of Project-Based Organizing in New Venture Creation: Projectification of an Entrepreneurial Ecosystem. International Journal of Managing Projects in Business, 11, Forthcoming.

Autio, E., Kenney, M., Mustar, P., Siegel, D., \& Wright, M. (2014): Entrepreneurial innovation: the importance of context. Research Policy, 43(7): 1097-1108.

Autio, E. and Thomas, L. D. W. 2014. Innovation ecosystems: Implications for innovation management. The Oxford Handbook of Innovation Management. Oxford University Press.

Baldock, R. 2015. What is the role of public feeder markets in developing technology-based small firms? An exploration of the motivations for listing on AIM since the GFC. Venture Capital, 17(1-2): 87-112.

Bathelt, H., Malmberg, A., and Maskell, P. 2004. Clusters and knowledge: local buzz, global pipelines and the process of knowledge creation. Progress in Human Geography, 28(1): 31-56.

Bakker, R. M. 2010. Taking stock of temporary organizational forms: A systematic review and research agenda. International Journal of Management Reviews, 12(4): 466-486.

Baumol, V. J. 1990. Entrepreneurship: Productive, Unproductive. The Journal of Political Economy, 98(5 Part 1): 893-921.

Becker, A., Knyphausen-Aufseß, D. Z., \& Brem, A. 2015. Beyond traditional developmental models: a fresh perspective on entrepreneurial new venture creation. International Journal of Entrepreneurial Venturing, 7(2): 152-172.

Bhave, M. P. 1994. A process model of entrepreneurial venture creation. Journal of Business Venturing, 9(3): 223-242. 
Børve, S., Rolstadås, A., Andersen, B., and Aarseth, W. 2017. Defining project partnering. International Journal of Managing Projects in Business, 10(4): 666-699.

Borissenko, J., and Boschma, R. 2017. A critical review of entrepreneurial ecosystems research-towards a future research agenda (No. 2017/3). Lund University, CIRCLE-Center for Innovation, Research and Competences in the Learning Economy.

Brown, R., and Mason, C. 2014. Inside the high-tech black box: A critique of technology entrepreneurship policy. Technovation, 34(12): 773-784.

Bruneel, J., Spithoven, A., and Clarysse, B. 2017. Interorganizational Trust and Technology Complexity: Evidence for New Technology-Based Firms. Journal of Small Business Management, 55(S1): 256-274.

Bruton, G. D., Ahlstrom, D., and Obloj, K. 2008. Entrepreneurship in emerging economies: Where are we today and where should the research go in the future. Entrepreneurship Theory and Practice, 32(1): 1-14.

Bruton, G. D., Su, Z., and Filatotchev, I. 2018. New venture performance in transition economies from different institutional perspectives. Journal of Small Business Management, 56(3): 374-391.

Burgelman, R. A. 1983. Corporate entrepreneurship and strategic management: Insights from a process study. Management Science, 29(12): 1349-1364.

Cannone, G., and Ughetto, E. 2014. Funding innovation at regional level: an analysis of a public policy intervention in the piedmont region. Regional Studies, 48(2): 270-283.

Cardon, M. S., Foo, M. D., Shepherd, D., and Wiklund, J. 2012. Exploring the heart: Entrepreneurial emotion is a hot topic. Entrepreneurship Theory and Practice, 36(1): 1-10. 
Carayannis, E. G., and Campbell, D. F. J. 2009. "mode 3" and "quadruple helix": toward a 21 st century fractal innovation ecosystem. International Journal of Technology Management, 46(3/4): 201234.

Casper, S., and Whitley, R. 2004. Managing competences in entrepreneurial technology firms: a comparative institutional analysis of Germany, Sweden and the UK. Research Policy, 33(1): 89106.

Chen, C. J., Li, Z., Su, X., \& Sun, Z. 2011. Rent-seeking incentives, corporate political connections, and the control structure of private firms: Chinese evidence. Journal of Corporate Finance, 17(2): 229-243.

Citroni, G., Lippi, A., and Profeti, S. 2013. Remapping the state: inter-municipal cooperation through corporatisation and public-private governance structures. Local Government Studies, 39(2): 208234.

Colombelli, A., Paolucci, E., and Ughetto, E. 2017. Hierarchical and relational governance and the life cycle of entrepreneurial ecosystems. Small Business Economics, 49: 1-17.

Colombo, M. G., Dagnino, G. B., Lehmann, E. E., and Salmador, M. 2017. The governance of entrepreneurial ecosystems. Small Business Economics, 49: 1-10.

Davidsson, P., and Gordon, S. R. 2012. Panel studies of new venture creation: a methods-focused review and suggestions for future research. Small Business Economics, 39(4): 853-876.

de Lange, D. E. 2016. Legitimation strategies for clean technology entrepreneurs facing institutional voids in emerging economies. Journal of International Management, 22(4): 403-415. 
Dutton, J. E., Ashford, S. J., O’neill, R. M., Hayes, E., \& Wierba, E. E. 1997. Reading the wind: How middle managers assess the context for selling issues to top managers. Strategic Management Journal, 18(5): 407-423.

Eisenhardt, K. M., and Graebner, M. E. 2007. Theory building from cases: Opportunities and challenges. Academy of Management Journal, 50(1): 25-32.

Engwall, M. 2003. No project is an island: linking projects to history and context. Research Policy, 32(5): 789-808.

Feld, B. 2012. Startup Communities: Building an Entrepreneurial Ecosystem in Your City. John Wiley \& Sons.

Ferry, L., Andrews, R., Skelcher, C., and Wegorowski, P. 2018. New development: Corporatization of local authorities in England in the wake of austerity 2010-2016. Public Money \& Management, 38(6): 477-480.

Flyvbjerg, B. 2006. Five Misunderstandings About Case-Study Research. Qualitative Inquiry, 12(2): 219245.

Grabher, G. 2002. Cool projects, boring institutions: temporary collaboration in social context. Regional studies, 36(3): 205-214.

Gartner, W. B. 1985. A conceptual framework for describing the phenomenon of new venture creation. Academy of Management Review, 10(4): 696-706.

Haas, P.M. 1992. "Introduction: epistemic communities and international policy coordination." International Organization, special issue 46 (1): 1-35.

Henrekson, M., and Johansson, D. 2010. Gazelles as job creators: a survey and interpretation of the evidence. Small Business Economics, 35(2): 227-244. 
Herrmann, A. M. 2010. Against the Schumpeterian mainstream: a review of institutional approaches to entrepreneurship. Socio-Economic Review, 8(4): 735-746.

Hillman, A. J., Keim, G. D., and Schuler, D. 2004. Corporate political activity: A review and research agenda. Journal of Management, 30(6): 837-857.

Hodge, I., and Adams, W. M. 2016. Short-term projects versus adaptive governance: Conflicting demands in the management of ecological restoration. Land, 5(4): 39-56.

Hornsby, J. S., Kuratko, D. F., Shepherd, D. A., and Bott, J. P. 2009. Managers' corporate entrepreneurial actions: Examining perception and position. Journal of Business Venturing, 24(3): 236-247.

Hosseini, A., Windimu, P., Klakegg, O., Andersen, B. and Laedre, O. 2018. Project Partnering in the Construction Industry: Theory vs. Practice. Engineering Project Organization Journal, 8, forthcoming.

Isenberg, D. 2014. What an entrepreneurship ecosystem actually is. Harvard Business Review, 5: 1-7.

Isenberg, D. J. 2010. How to start an entrepreneurial revolution. Harvard Business Review, 88(6): 40-50.

Isenberg, D., \& Onyemah, V. 2016. Fostering scaleup ecosystems for regional economic growth. Innovations: Technology, Governance, Globalization, 11(1-2): 60-79.

Jiang, Y., \& Tornikoski, E. T. 2019. Perceived uncertainty and behavioral logic: Temporality and unanticipated consequences in the new venture creation process. Journal of Business Venturing, 34(1): 23-40.

Johnston, L., Robinson, S. and Lockett, N. 2010. Recognising “open innovation” in HEI-industry interaction for knowledge transfer and exchange. International Journal of Entrepreneurial Behaviour \& Research, 16(6): 540-560. 
Jong, S. 2006. How organizational structures in science shape spin-off firms: The biochemistry departments of Berkeley, Stanford, and UCSF and the birth of the biotech industry. Industrial and Corporate Change, 15(2): 251-283.

Kao, J. J. 1991. The Entrepreneur. Englewood Cliffs, NJ: Prentice Hall.

Kenney, M., and Patton, D. 2005. Entrepreneurial geographies: Support networks in three hightechnology industries. Economic Geography, 81(2): 201-228.

Kleiner, M. M., and Krueger, A. B. 2013. Analyzing the extent and influence of occupational licensing on the labor market. Journal of Labor Economics, 31(S1): S173-S202.

Kuratko, D. F., and J. S. Hornsby. 2017. New Venture Management: The Entrepreneur's Roadmap. New York and London, Routledge.

Lam, W. 2004. New venture creation in two Chinese subcultures: Hong Kong and Shanghai. PhD dissertation, Nottingham Trent University.

Lenarduzzi, V., and Taibi, D. 2016. MVP explained: A systematic mapping study on the definitions of minimal viable product. In Software Engineering and Advanced Applications (SEAA), 2016 42th Euromicro Conference on (pp. 112-119). Cyprus, IEEE.

Lerner, J. 2002. When bureaucrats meet entrepreneurs: the design of effective public venture capital programmes. Economic Journal, 112(477): F73-F84.

Lindgren, M., and Packendorff, J. 2003. Deconstructing Projects: Towards Critical Perspectives on Project Theory and Projecticised Society. In Making Projects Critical: A Crisis of Instrumental Rationality? April 10-11, 2003, Bristol Business School, Bristol, UK.. University of the West of England. 
Liu, J.X., and Xing, J.F. 2009. Application of process management in design management of large scale air separation projects. Cryogenic Technology, 2009(4), 35-38.

Liu, X., Schwaag Serger, S., Tagscherer, U., and Chang, A. Y. 2017. Beyond catch-up-Can a new innovation policy help China overcome the middle income trap? Science and Public Policy, 44(5): 656-669.

Lundin, R. A., and Söderholm, A. 1995. A theory of the temporary organization. Scandinavian Journal of Management, 11(4): 437-455.

Lundin, R. A., Arvidsson, N., Brady, T., Ekstedt, E., \& Midler, C. (2015). Managing and working in project society: Institutional Challenges of Temporary Organizations. Cambridge: Cambridge University Press.

Mason, C., and Brown, R. 2014. Entrepreneurial ecosystems and growth oriented entrepreneurship. Final Report to OECD, Paris, 30(1): 77-102.

Midler, C., and Silberzahn, P. 2008. Managing robust development process for high-tech startups through multi-project learning: The case of two European start-ups. International Journal of Project Management, 26(5): 479-486.

Midler, C. 1995. Projectification of the firm: The Renault case. Scandinavian Journal of Management, 11 (4): 363-375.

Millman, C., \& Li, Z. 2017. Establishing a viable institutional environment for entrepreneurship in China: A case study of Zhejiang province. Strategic Change, 26(3): 237-242.

Minà, A., and Dagnino, G. B. 2017. Mapping entrepreneurial ecosystems inquiry: a content analysis of the literature and its implications. Entrepreneurial ecosystems and the diffusion of startups, Northampton, MA: Edward Elgar. In press. Google Scholar. 
Nonaka, I., and Takeuchi, H. 1995. The knowledge creation company: How Japanese companies create the dynamics of innovation. New York: Oxford University Press

Neck, H. M., Meyer, G. D., Cohen, B., and Corbett, A. C. 2004. An entrepreneurial system view of new venture creation. Journal of Small Business Management, 42: 190-208.

O’Connor, A., Stam, E., Sussan, F., and Audretsch, D. B. 2018. Entrepreneurial Ecosystems: The Foundations of Place-based Renewal. In Entrepreneurial Ecosystems. 1-21. Cham: Springer.

Pitelis, C. 2012. Clusters, entrepreneurial ecosystem co-creation, and appropriability: A conceptual framework. Industrial and Corporate Change, 21(6): 1359-1388.

Rethelyi, J. M., Miskovits, E., and Szocska, M. K. 2002. Organizational Reform in the Hungarian Hospital Sector: Institutional Analysis of Hungarian Hospitals and the Possibilities of Corporatization. <journal article?>

Ries, E. 2011. The Lean Startup: How Today's Entrepreneurs Use Continuous Innovation to Create Radically Successful Businesses. New York: Crown Business.

Rivas, L. 2014. Creating a classroom makerspace. Educational Horizons, 93(1), 25-26.

Roberts, P. 2011. Effective Project Management: Identify and Manage Risks Plan and Budget Keep Projects Under Control. London: Kogan Page.

Rong, K., and Shi, Y. 2014. Business Ecosystems: Constructs, Configurations, and the Nurturing Process. London: Palgrave Macmillan.

Salmador, M. P., and Bueno, E. 2005. Strategy-Making as a complex, double-loop process of knowledge creation: four cases of established banks reinventing the industry by means of the internet. In Strategy Process (pp. 267-318). West Yorkshire: Emerald Group. 
Salamzadeh, A., \& Kirby, D. A. (2017). New venture creation: How start-ups grow? AD-minister, 30: 9-29.

Sarasvathy, S. D., Menon, A. R., and Kuechle, G. 2013. Failing firms and successful entrepreneurs: Serial entrepreneurship as a temporal portfolio. Small Business Economics, 40(2): 417-434.

Schjoedt, L., \& Kraus, S. 2009. Entrepreneurial teams: definition and performance factors. Management Research News, 32(6): 513-524.

Shane, S. 2009. Why encouraging more people to become entrepreneurs is bad public policy. Small Business Economics, 33(2): 141-149.

Shaver, K. G., and Scott, L. R. 1992. Person, process, choice: The psychology of new venture creation. Entrepreneurship Theory and Practice, 16(2): 23-46.

Söderblom, A., Samuelsson, M., Wiklund, J., and Sandberg, R. 2015. Inside the black box of outcome additionality: Effects of early-stage government subsidies on resource accumulation and new venture performance. Research Policy, 44(8): 1501-1512.

Spigel, B. 2017. The relational organization of entrepreneurial ecosystems. Entrepreneurship Theory and Practice, 41(1): 49-72.

Spigel, B., and Harrison, R. 2018. Toward a process theory of entrepreneurial ecosystems. Strategic Entrepreneurship Journal, 12(1): 151-168.

Stam, E. 2015. Entrepreneurial ecosystems and regional policy: a sympathetic critique. European Planning Studies, 23(9): 1759-1769.

Stam, F. C., and Spigel, B. 2016. Entrepreneurial ecosystems. USE Discussion paper series, 16(13).

Thomas, H. G. 1999. Managerial implications of adopting formula-based systems of resource allocation: A case study from higher education. Educational Management \& Administration, 27(2): 183-191. 
Tolbert, P.S., David, R.J., and Sine, W.D. 2011. Studying choice and change: the intersection of institutional theory and entrepreneurship research. Organization Science, 22(5): 1332-1344.

Tweney, D. 2009. DIY freaks flock to 'hacker spaces' worldwide. Wired. Accessed April 13, 2013.

Valdez, J. 1988. The entrepreneurial ecosystem: Toward a theory of new business formation. Small Business Institute Director's Association.

Van de Ven, A. H. (2007). Engaged scholarship: A guide for organizational and social research. Oxford University Press.

Voorn, B., van Thiel, S., and van Genugten, M. 2018. Debate: Corporatization as more than a recent crisis-driven development. Public Money \& Management, 38(7): 481-482.

Walsh, I. J., Bhatt, M., and Bartunek, J. M. 2009. Organizational knowledge creation in the Chinese context. Management and Organization Review, 5(2): 261-278.

Welch, C., Piekkari, R., Plakoyiannaki, E., and Paavilainen-Mäntymäki, E. 2011. Theorising from case studies: Towards a pluralist future for international business research. Journal of International Business Studies, 42(5): 740-762.

Yan, Z., \& Li, Y. 2018. Signaling through government subsidy: Certification or endorsement. Finance Research Letters, 25: 90-95.

Yiu, D. W., Hoskisson, R. E., Bruton, G. D., and Lu, Y. 2014. Dueling Institutional Logics and the Effect on Strategic Entrepreneurship in Chinese Business Groups. Strategic Entrepreneurship Journal, 8(3): 195-213.

Yin, R. K. 2014. Case Study Research: Design and Methods. 5th ed. ed. Los Angeles: SAGE.

Zhang, W., and White, S. 2016. Overcoming the liability of newness: Entrepreneurial action and the emergence of China's private solar photovoltaic firms. Research Policy, 45(3): 604-617. 
Figure 1: Overview of Data Structure

- Preference of talents (called new four(th) army)

- Serial entrepreneur with successful story

- First-time entrepreneur with prior experience in tech, product, market

- Challenge Seminar for Entrepreneurial idea

- Monthly come-on campaign as contest and top 20 projects are selected

- Outstanding project direct shift-in

- Free workplace for selected entrepreneurial projects

- Logistics and management for daily operation for entrepreneur (and team)

- Innovation vouchers for professional service in legal, HR, finance, IP etc

- Recommend the key personal upon request

- Complementary team members in terms of competence and capability

- Team interaction in formal / informal environment

- Regular communication at Epistemic community

- Mentoring Clinics

- Product knowledge creation and/or acquisition

- Seed \& Angle capital for secure product materialization

- Access to external resource (business partner and investment institutions)

- Product verification for functionality (MVP) and marketability

Identity of Entrepreneur

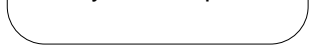

Entrepreneurial Project

Evaluation

Supplies of Direct Subsidy
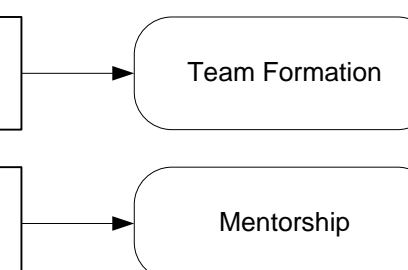

Provision of Seed \& Angel Capital

- Legitimacy of new venture

- Trust establishment between new venture and resource provider

- Operability and quality of new venture verification

- Being shareholder with prior-angle investment

- Exposure at public fair, conference, close-door meeting

- Use of media (video, brochure, website)

- Bank's investment-load linkage program

- Equity assessment for investment institution

- Government's industry-guiding fund

Intermediary for financing program 
Figure 2: Government's Role in New Venture Creation in the Entrepreneurial Ecosystem

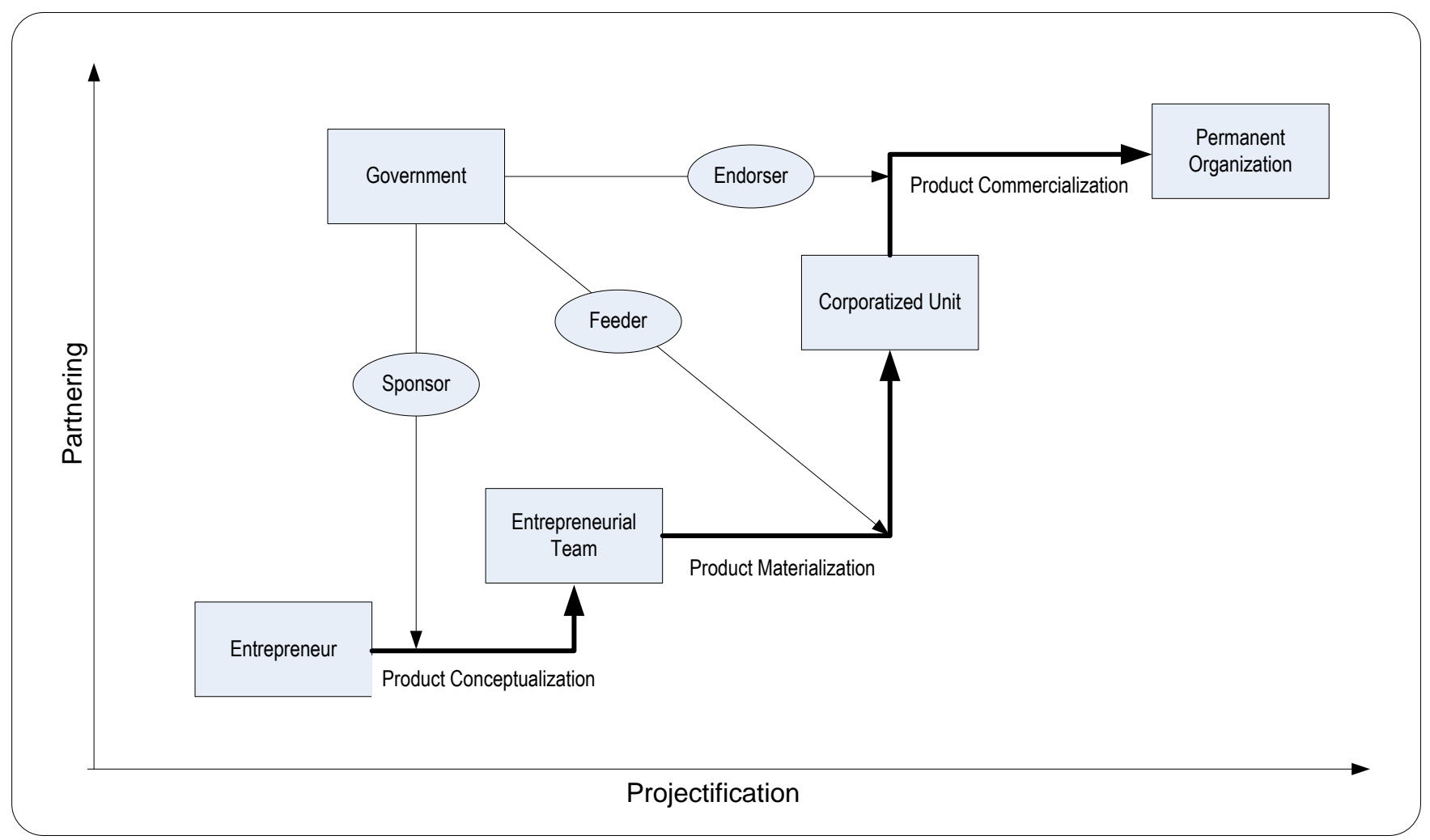


Table 1: Two newly established entrepreneurial firms

\begin{tabular}{c|cc}
\hline & Case 1 (Poly Health) & Case 2 (Medoxygen) \\
\hline Founded & Sept. 2015 & Feb. 2016 \\
Product \& service & Health-care service management & Medical oxygen one-stop solution \\
Reg. Capital (mill. RMB) & 10 & 3 \\
Business orientation & Market oriented & Technology oriented \\
Incubator \& accelerator & Turtle & Liangcang \\
\hline
\end{tabular}


Table 2: Distribution of Interviewees by Role and Key Issues

\begin{tabular}{|c|c|c|c|c|}
\hline & $\begin{array}{l}\text { Role of } \\
\text { interviewee }\end{array}$ & Times & $\begin{array}{l}\text { Total } \\
\text { Hours }\end{array}$ & Key issues \\
\hline \multirow[t]{4}{*}{$\begin{array}{l}\text { Case } 1 \\
\text { Poly Health }\end{array}$} & CEO & 5 & 15 & $\begin{array}{l}\text { Business plan; business strategy, product development, business } \\
\text { development, organization, financing, business partner, } \\
\text { incubation and acceleration }\end{array}$ \\
\hline & $\begin{array}{l}\text { Assistant to } \\
\text { CEO }\end{array}$ & 3 & 7.5 & $\begin{array}{l}\text { Team form and building, legal registration, training, intermediary } \\
\text { service, incubation and acceleration }\end{array}$ \\
\hline & $\begin{array}{l}\text { Marketing } \\
\text { Manager }\end{array}$ & 2 & 4 & $\begin{array}{l}\text { Marketable product, business development, customer } \\
\text { participation and partnering }\end{array}$ \\
\hline & $\begin{array}{l}\text { APP program } \\
\text { manager }\end{array}$ & 3 & 6.5 & $\begin{array}{l}\text { Minimum viable product, technology dependency, R\&D team, } \\
\text { product cycle time, product management }\end{array}$ \\
\hline \multirow[t]{5}{*}{$\begin{array}{l}\text { Case } 2 \\
\text { Medoxygen }\end{array}$} & President & 4 & 12 & $\begin{array}{l}\text { Business plan, business strategy, product development, business } \\
\text { development, organization, financing, business partner, } \\
\text { incubation and acceleration, government relationship }\end{array}$ \\
\hline & $\begin{array}{l}\text { Managing } \\
\text { Director }\end{array}$ & 4 & 15.5 & $\begin{array}{l}\text { Product registration, product development, product portfolio } \\
\text { management, business development, organization, financing, } \\
\text { business partner, incubation and acceleration }\end{array}$ \\
\hline & Chief Engineer & 3 & 7 & $\begin{array}{l}\text { Minimum viable product, intelligent property, technology } \\
\text { dependency, R\&D team, product cycle time, product management }\end{array}$ \\
\hline & $\begin{array}{l}\text { Director of } \\
\text { business } \\
\text { development } \\
\text { and sales }\end{array}$ & 2 & 5 & $\begin{array}{l}\text { Marketable product, business development, market strategy, } \\
\text { customer participation and partnering }\end{array}$ \\
\hline & $\begin{array}{l}\text { Administrative } \\
\text { Manager }\end{array}$ & 3 & 6.5 & $\begin{array}{l}\text { Team form and building, legal registration, training, intermediary } \\
\text { service, incubation and acceleration }\end{array}$ \\
\hline \multirow[t]{3}{*}{ Government } & $\begin{array}{l}\text { Acting dean of } \\
\text { DTSCO (ZPG) }\end{array}$ & 3 & 5 & $\begin{array}{l}\text { Deployment (vision, culture, policies), entrepreneurial project } \\
\text { collection and evaluation, resources allocation (capital and } \\
\text { networking), government's involvement and intervention }\end{array}$ \\
\hline & $\begin{array}{l}\text { Deputy Head of } \\
\text { HFSCMC }\end{array}$ & 2 & 4 & $\begin{array}{l}\text { Deployment (vision, culture, policies), entrepreneurial project } \\
\text { collection and evaluation, resources allocation (capital and } \\
\text { networking), government's involvement and intervention }\end{array}$ \\
\hline & $\begin{array}{l}\text { General } \\
\text { Manager of } \\
\text { Greenroot }\end{array}$ & 2 & 5 & $\begin{array}{l}\text { Entrepreneurial activities, entrepreneurial project collection and } \\
\text { evaluation, partnering agreement, new venture registration, } \\
\text { professional service provider }\end{array}$ \\
\hline \multirow{3}{*}{$\begin{array}{l}\text { Investment } \\
\text { Institution }\end{array}$} & Jinkong & 3 & 7 & \multirow{3}{*}{$\begin{array}{l}\text { Capital and capital supply procedure, project evaluation, } \\
\text { investment confidence, risk management, equity exchange (entry } \\
\text { and exit) }\end{array}$} \\
\hline & Lvkang & 2 & 4.5 & \\
\hline & Zhiqiao & 3 & 6.5 & \\
\hline
\end{tabular}

